\title{
SHOREBIRDS ECOLOGY AND CONSERVATION WORKSHOP CONVENES AT CHAPLIN LAKE
}

\author{
Monica Iglecia, Brad Winn \\ and Brian Harrington \\ Manomet. P.O. Box 1770 \\ Manomet, MA 02345, USA \\ Jordan Ignatiuk \\ Nature Saskatchewan \\ 1860 Lorne St. \\ Regina, SK S4P 2 L7

\section{Christy Morrissey \\ University of Saskatchewan \\ 112 Science Place \\ Saskatoon, SK S7N 5E2 \\ Lori Wilson \\ Chaplin Nature Centre \\ Box 57, Chaplin, SK SOH 0V0} \\ Corresponding address: \\ Manomet Box 1770 \\ Manomet, MA 02345 \\ miglecia@manomet.org
}

Shorebirds are a widely diverse group of birds in the order Charadriiformes represented in North America by four families: Charadriidae (plovers), Haematopodidae (oystercatchers), Recurvirostridae (stilts and avocets), and the largest family, Scolopacidae (sandpipers, snipes, and phalaropes). Characterized for their strong affinity to shallow water habitat and open areas, shorebirds rely on a variety of locations throughout the year along their migratory routes, including coastlines, wetlands, and saline lakes.

Migratory shorebird populations have declined 70 per cent in the last four decades. ${ }^{1}$ Some of the major threats to shorebirds include habitat loss and degradation, disturbance by humans during breeding and migration, and a series of complicating factors due to a changing climate..$^{2,3}$ In Saskatchewan, nearly 40 per cent of wetlands have been lost to drainage and degradation and nearly 10,000 acres of wetlands are drained each year. ${ }^{4,5}$ Appropriate land management has the potential to alleviate some of the threats to shorebird populations. Through regional shorebird conservation workshops, we can engage and educate land managers, land owners, and biologists and provide advisement of land management strategies that can improve habitats for shorebirds.

In late May 2016, Manomet's Shorebird Recovery Program's Habitat Management Team cohosted a "Shorebird Ecology, Conservation, and Habitat Management workshop" in Chaplin, Saskatchewan, in collaboration with Nature Saskatchewan, the Chaplin Nature Centre and the University of Saskatchewan. The goals of the workshop were to bring together and train land managers, biologists, and other conservation professionals in the topics of shorebird ecology and habitat needs and to discuss threats to shorebird populations and opportunities for conservation efforts.

Prairie Canada, rich with wetlands, spans three provinces (Alberta, Manitoba, and Saskatchewan) and is part of the great Central Flyway, a migratory bird superhighway that links breeding grounds in the Arctic with wintering grounds in the southern United States and Central and South America. Canadian prairie habitats and associated wetlands support 25 breeding shorebird species and provide fall and spring migration habitat for 31 species (Fig. 1). ${ }^{6}$ For some shorebird species, the prairies provide the only breeding habitat in Canada. Some of these prairie-breeding shorebirds include
Willet (Tringa semipalmata), Upland Sandpiper (Bartramia longicauda, Fig. 2), American Avocet (Recurvirostra americana), Piping Plover (Charadrius melodus, listed under Species at Risk Act), and Marbled Godwit (Limosa fedoa).

During our workshop, field excursions focused on the Chaplin, Old Wives, and Reed lakes, a Western Hemisphere Shorebird Reserve Network (WHSRN) Site of Hemispheric Importance (http:// www.whsrn.org/site-profile/chaplinold-wives-reed-lakes) used by 30 shorebird species and up to 30 per cent of the global population of Sanderling (Calidris alba). In late May, the arctic-nesting Red Knots (Calidris canutus) and Black-bellied Plovers (Pluvialis squatarola) using Chaplin and Reed Lakes are preparing to move further north to the breeding areas (Fig. 3). We encountered at least 450 Red Knots as they roosted on the abandoned road on Reed Lake and foraged along the lake edge and in nearby agricultural fields. We sighted two knots with colored flags on their upper legs. Both birds had been flagged by David Newstead of the Coastal Bend Bays and Estuaries Program in coastal Texas, highlighting the connectivity between the central coast of the United States and inland lakes and wetlands in the prairie pothole region of the northern United States and Canada.

Workshop discussions included shorebird ecology at a hemispheric scale, as well as local topics and overarching conservation efforts across the Canadian prairies. Presentations were given by Manomet staff and a variety of regional professionals and scientists. 


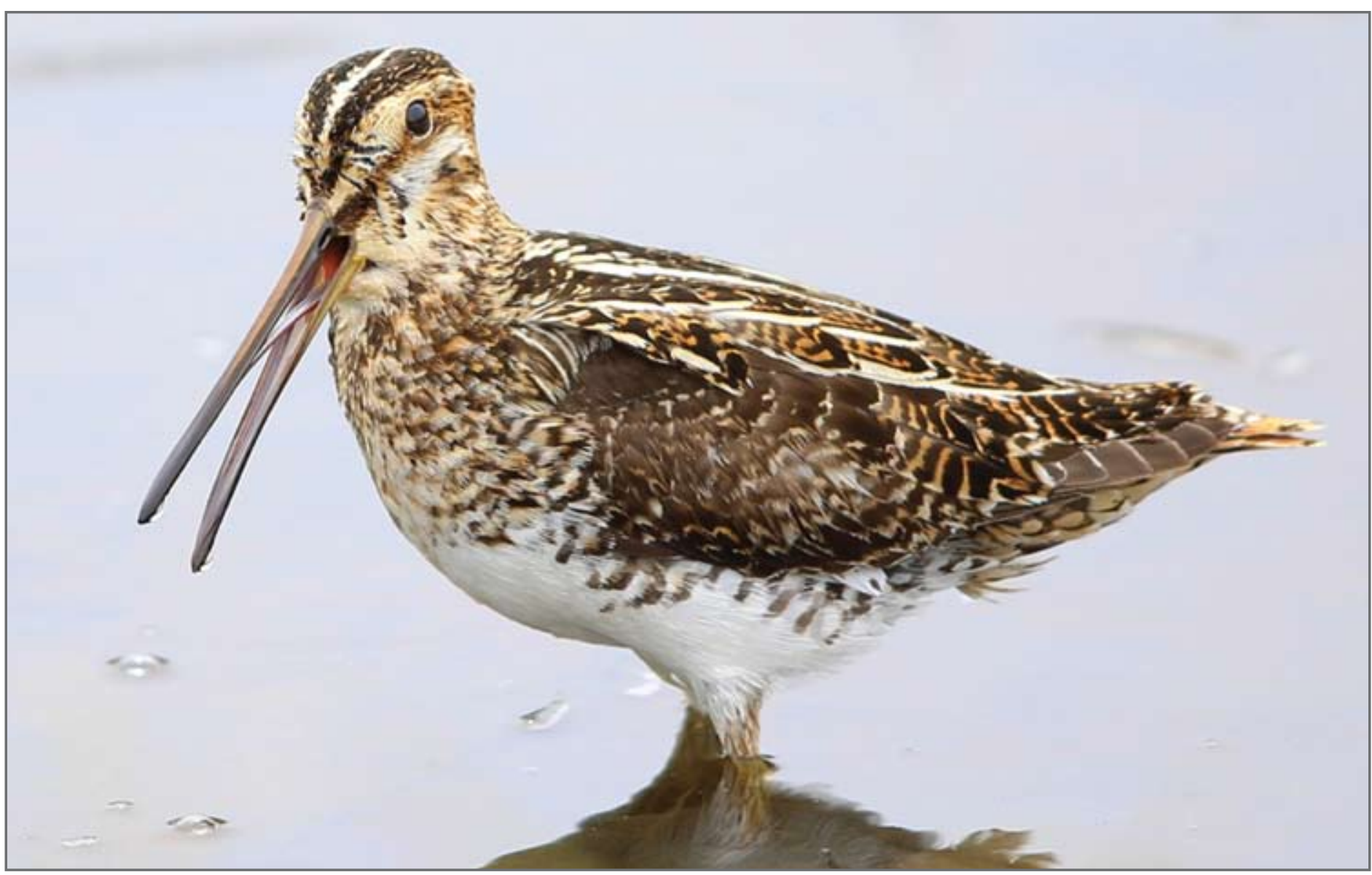

Figure 1. A Wilson's Snipe calls to its mate. Photo credit: Brad Winn

Dale Hjertaas with the Saskatchewan Water Security Agency provided the local geologic and landscape context for the importance of the region to shorebirds. Dr. Christy Morrissey with the University of Saskatchewan presented her lab's research on the impacts of wind farms and pollution threats to shorebirds in the Central Flyway. Dr. Morrissey and her graduate students also provided a tour of the Motus tracking system they are using to understand Sanderling and Red Knot movements in the region. Lori Wilson of the Chaplin Nature Centre discussed the Linking Communities program (http://utahlinking.org/), a tri-national partnership between three sites in the Western Hemisphere Shorebird Reserve Network that share the same shorebirds and have developed a joint program of wetland bird conservation, environmental education and ecotourism:
Chaplin and associated lakes in Saskatchewan, Canada; Great Salt Lake in Utah, United States of America; and Marismas Nacionales in Nayarit, Mexico. Alan Smith of Nature Saskatchewan described the past and current status of the long-term International Piping Plover Breeding Census in the ephemeral prairie habitats in Saskatchewan. Rebecca Magnus of Nature
Saskatchewan shared the Stewards of Saskatchewan program, which includes local habitat management efforts and collaboration with private landowners to further Piping Plover conservation in the region. Dr. Ann McKellar from Environment and Climate Change Canada presented results of shorebird monitoring and conservation efforts in the Prairie Provinces.

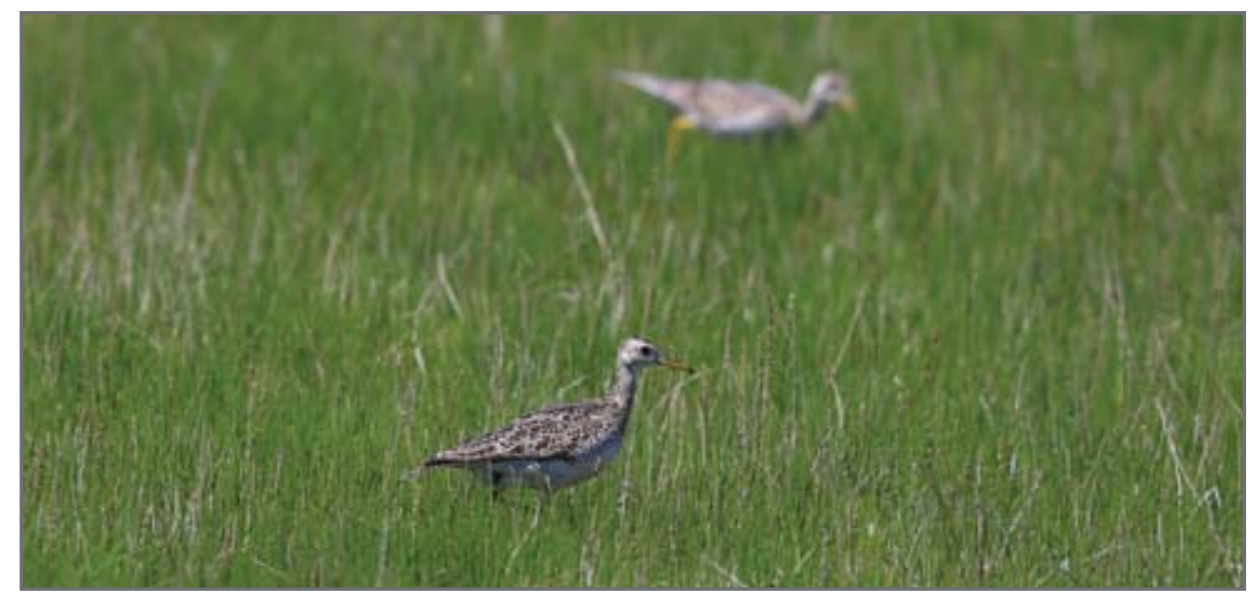

Figure 2. A pair of Upland Sandpipers forage along the edges of Chaplin Lake, Saskatchewan. Photo credit: Brad Winn 




The 35 workshop participants in attendance came from all three Prairie Provinces and included university professors and students as well as biologists and land managers from non-profits, provincial and federal agencies, and environmental consultants (Fig. 4). Among the workshop participants were seven individuals that had also attended the first-of-its-kind shorebird workshop in the Canadian prairies in May of 1999 at the recently designated Western Hemisphere Shorebird Reserve Network Site of Chaplin, Old Wives, and Reed lakes (Fig. 5). Brian Harrington of Manomet had collaborated with the Saskatchewan Wetland Conservation Corporation and Ducks Unlimited Canada to hold the event. Today, each of the returning workshop participants plays a significant role in bird conservation

Figure 3. Red Knots and Black-bellied Plovers roost at Reed Lake, Saskatchewan. Photo credit: Monica Iglecia

and we had the opportunity to learn more about a couple of the returning participants.

Michael Barr attended the 1999 shorebird workshop as an avid bird enthusiast and Ducks Unlimited Canada biologist. His interest in shorebirds was ignited just prior to the workshop, after collaborating with Environment Canada in nominating Beaverhill Lake as a WHSRN site, the first and only in Alberta. In his current capacity as the North American Waterfowl Management Plan Coordinator in Alberta, Michael says he is in a position to help raise the profile and enable shorebird conservation action in Alberta and across Prairie Canada through the Prairie Habitat Joint Venture. Michael stated that the workshop had reinspired his interest in shorebirds and that "Manomet's workshops bring much needed attention, knowledge, and enthusiasm to resource managers and biologists to act on the needs of shorebirds."

Barbara Hanbidge attended the workshop in 1999 and said that the workshop gave her the skills to identify shorebirds and their habitats. Since then, Barbara has influenced wetland management in ways that benefit shorebirds and other waterbirds in Saskatchewan throughout her career with Ducks Unlimited Canada. Barbara says she returned for the second workshop in 2016 to learn more and to stay connected with the latest in shorebird conservation efforts. Today, Barbara is a Provincial Policy Specialist in Saskatchewan and a longtime resident near Chaplin Lake.

Both the 1999 and the 2016 shorebird workshops benefitted from 




the enthusiasm and expertise of the Chaplin Lake Nature Centre's staff (chaplintourism.com). The Centre embodies the spirit of the Western Hemisphere Shorebird Reserve Network (www.whsrn.org), which relies on local support and expertise for the management and protection of strategic shorebird migration stopover sites. The Nature Centre and its allies have done an impressive job engaging the public and providing site stewardship.

The workshop participants this spring in Chaplin included conservation professionals of a variety of ages and stages in their careers. It was a pleasure to meet them all, from the students to the seasoned professionals. We all have much to learn from each other as we work to conserve our shared shorebirds across international boundaries. It was quite

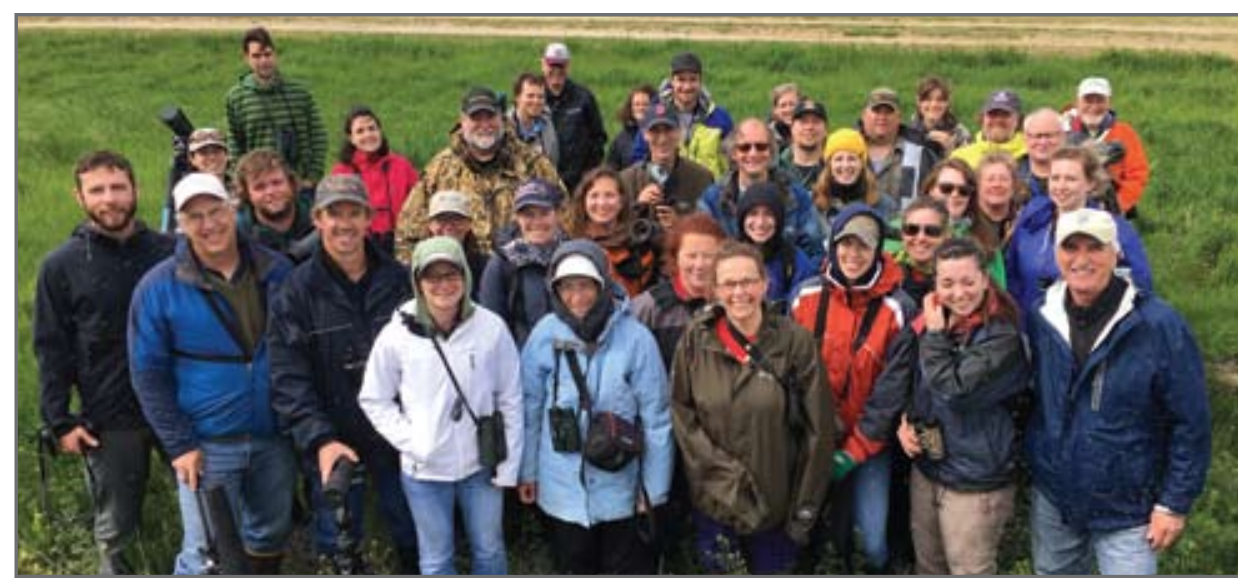

Figure 4. The 2016 workshop participants visit Reed Lake, Saskatchewan. Photo credit: Brad Winn

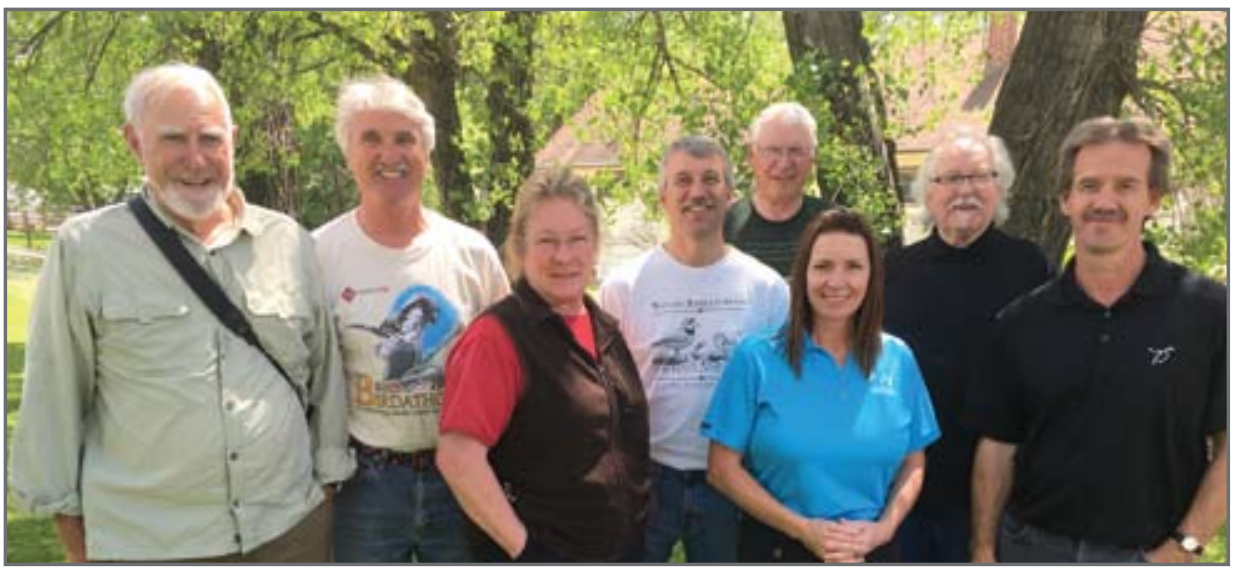

Figure 5. From left to right: Brian Harrington and returning workshop participants Michael Barr, Barbara Hanbidge, Jordan Ignatiuk, Clem Millar, Lori Wilson, Alan Smith, and Andrew Hak. Photo credit: Brad Winn

the experience to reconnect with the individuals that have committed themselves to the conservation of the critical habitats in the Canadian prairies and to meet some of the next generation eager to make a difference.

\section{North American Bird Conservation} Initiative (2016) The State of North America's Birds 2016. Environment and Climate Change Canada: Ottawa, Ontario. 8 pages.

www.stateofthebirds.org

2. Canadian Wildlife Service (2000)

Canadian Shorebird Conservation Plan. Unpublished report prepared by the Canadian Wildlife Service. Donaldson GM, Hyslop C, Morrison RIG, Dickson HL, Davidson I (eds) Environment Canada, Ottawa, Ontario K1A OH3

3. Van Gils JA, Lisovski S, Lok T, Meissner W, Ozarowska A, de Fouw J, Rakhimberdiev E, Soloviev MY, Piersma T, Klaassen M (2016) Body shrinkage due to Arctic Warming Reduces Red Knot Fitness in
Tropical Wintering Range. Science 6287: 819-821.

4. Huel D (2000) Managing Saskatchewan Wetlands A Landowners Guide. Saskatchewan Wetland Conservation Corporation. Regina, Saskatchewan. Accessed June 24, 2016. www.southsaskriverstewards. ca/ckfinder/userfiles/files/

ManagingSaskatchewanWetlands.pdf?PH PSESSID=hr0j0knlod1 uqiveg37873n1u0

5. Ducks Unlimited Canada (2015) Ducks Unlimited Canada: Campaign for a Better Future. Accessed June 24, 2016. http:// www.marketwired.com/press-release/ ducks-unlimited-canada-campaign-for-abetter-future-2060308.htm

6. Prairie Habitat Joint Venture (2000) Prairie Canada Shorebird Conservation Plan. Unpublished Report prepared by the PHJV Prairies Canada Shorebird Conservation Plan Drafting Committee. Edmonton, Alberta. Accessed June 24, 2016. www.phjv.ca/pdf/Prairie\%20Canada $\% 20$ Shorebird\%20Conservation \%20Plan.pdf 